\title{
Beach nourishment is not a sustainable strategy to mitigate climate change
}

\author{
Randall W. Parkinson ${ }^{\mathrm{a},}{ }^{*}$ and Danielle E. Ogurcak ${ }^{\mathrm{b}}$ \\ a Sea Level Solutions Center, Florida International University, Miami, Florida 33199 \\ ${ }^{b}$ Institute for Water and Environment, Florida International University, Miami, Florida 33199 \\ *Corresponding author; rparkins@fiu.edu
}

\begin{abstract}
Some studies published over the past several decades have concluded nourishment of oceanic beaches is a viable strategy to mitigate climate change. However, these were generally too limited in scope to accurately evaluate beach nourishment because each omit one or more of the following: (1) a realistic assessment of potential borrow area sand volume, (2) native beach compatibility, (3) construction costs, (4) all vulnerable geomorphic elements of the coastal zone, and (5) environmental impacts. When all of these parameters are considered, the results are markedly different. To demonstrate our point, we evaluated the recommendations of Houston (2017) using all five parameters. Contrary to Houston, we provide multiple lines of evidence that beach fill projects are not a sustainable strategy to protect or defend oceanic beaches of the Florida panhandle (USA), nor likely most of the world's developed coastlines at risk to the effects of climate change. The nourishment of oceanic beaches as historically constructed will surely continue over the next several decades. But, it must be done as an interim strategy during the formulation and implementation of a robust, long-term adaptive management strategy that incorporates managed withdrawal from the coastline.
\end{abstract}

\section{Introduction}

The rate of global eustatic sea level has accelerated as a consequence of human-caused climate change, averaging about $2 \mathrm{~mm} \mathrm{yr}^{-1}$ since 1900 and over $3 \mathrm{~mm} \mathrm{yr} \mathrm{ym}^{-1}$ since 1993 (Church and White, 2011). Relative to the year 2000 , sea level is very likely to rise $30-130 \mathrm{~cm}$ by 2100 (Sweet et al., 2017). An increase in the number of intense tropical cyclones is also predicted as the climate warms (USGCRP, 2017). Both of these phenomena are already impacting the coastal zone, as evidenced by expanded nuisance flooding, submergence of low lying areas, increased erosion, wetland loss, and salt water intrusion into aquifers and rivers. Future climate change will exacerbate the frequency, duration, and extent of these phenomena (Bird, 1985; National Research Council, 1987; Nicholls et al., 2007; Nicholls and Cazenave, 2010).

Historically, a wide range of shore protection installations have been constructed to mitigate coastal erosion and flooding (climate change), including 'hard' (i.e., seawalls, groins, breakwaters, revetments) and 'soft' (i.e., dune construction, beach nourishment) structures (c.f. National Research Council, 1987). The currently preferred approach is beach filling (Peterson et al., 2006) or hereafter nourishment because hard structural solutions have been 
shown to have detrimental effects on adjacent beaches and coastal ecology (c.f. Cooke et al., 2012; Hamm et al., 2002). Also, the construction and maintenance costs of hard structures are much higher than nourishment (Hoffman, 2016; Leatherman, 1996).

A number of studies have been conducted to assess the viability of beach nourishment as a cost-effective, long-term management strategy to mitigate climate change. These typically include an assessment of potential offshore sand reserve volume (Leatherman, 1996; Titus et al., 1991) and an economic analysis to determine the extent and/or cost of requisite nourishment (Hinkel et al., 2013; Langedijk, 2008; National Research Council, 1995; Yoshida et al., 2014). While these studies should be considered an important first step, there exist several significant limitations to the scope of each. First, volume estimates of potential marine sand reserves are generally based upon limited (i.e., reconnaissance-level surveys) data, making it highly likely the volume of recoverable sand will be much less than initially calculated. Second, cost estimates are often based upon existing market conditions. Third, in no case was native beach compatibility considered, nor the full extent of associated environmental impacts.

This investigation was precipitated by the recent publication of Houston (2017), in which he states annual beach nourishment along more than three-hundred kilometers of Florida panhandle shoreline (Figure 1) can offset the effects of a sea level rise of between $0.38 \mathrm{~m}$ and $0.68 \mathrm{~m}$ (Church et al., 2013) by the year 2100. However, like the global (Hinkel et al., 2013), hemispheric (Hamm et al., 2002), national (Leatherman, 1989; National Research Council, 1987; Yoshida et al., 2014), and regional (Langedijk, 2008) assessments that preceded Houston (2017), the analysis was too limited in scope to accurately evaluate beach nourishment as a viable mitigation strategy. A more realistic assessment should consider: (1) potential marine sand reserve volume, (2) native beach compatibility, (3) construction costs, (4) all vulnerable geomorphic elements of the coastal zone, and (5) environmental impacts. When all of these parameters are considered, the results are markedly different. To demonstrate this point, the Florida panhandle study was evaluated using all of these parameters and the results clearly indicate beach nourishment is not a sustainable strategy to mitigate the effects of climate change along the Florida panhandle. Nor is beach nourishment likely a sustainable strategy to protect and defend most of the world's developed coastlines at risk to the effects of climate change.

\section{Background}

The coastal zone of the Florida panhandle is at high risk to climate change given its low elevation, erodible substrates, present and past evidence of shoreline retreat, and high probabilities of tropical storm and hurricane landfall (storms) (Gornitz et al., 1994). Based upon an analysis of coastal data collected since the 1800s, the annual placement of roughly $1.57 \mathrm{~m}^{3}$ to 2.42 million $\mathrm{m}^{3}$ (Table 1) of sand on $334 \mathrm{~km}$ of Gulf Coast oceanic shoreline is required to mitigate future impacts of sea level rise (Houston, 2017). Consideration of beach nourishment as a viable strategy to combat sea level rise is not new (c.f., Langedijk, 2008; Leatherman, 1989; 
Yoshida et al., 2014). In reality however, it is unlikely the requisite scale of construction could be sustained given what is known about compatible marine sand reserves and ballooning costs.

\section{Marine sand reserve volume}

Permitted borrow areas along the Florida panhandle are located proximal to the coastline $(<5$ $\mathrm{km})$, in relatively shallow water $(<15 \mathrm{~m})$, are of limited horizontal scale $(<1 \mathrm{~km})$, and typically contain less than 2 million cubic yards of sand (Figure 2, Supplemental Table 2). Most of these have already been utilized or will be dredged in the next decade. Remaining permitted borrow areas are scant and will not meet the long-term volume requirements to sustain a nourishment campaign along the Florida panhandle to the end of this century.

By contrast, most potential sand reserves along the Florida panhandle are located more than 10 $\mathrm{km}$ offshore and in water depths exceeding 15 meters (Figure 2). Although identified primarily by limited, reconnaissance-level geophysical surveys, these areas could yield Houston's requisite sand volumes for all seven counties through the end of this century.

\section{Marine sand reserve compatibility}

According to Florida Law (Chapter 62B-41), the sand used for beach nourishment must be similar to the characteristics of native beach sediment. Defined as beach compatible fill, this material is mandated in an attempt to maintain the general character and function of Florida's native beaches. The principle characteristics used to assess compatibility are sediment texture (i.e., size, sorting), composition (i.e., percent carbonate), and color.

The native beaches of the Florida panhandle consist of fine-grained, well to moderately-well sorted, white sand (Figure 3, Supplemental Table 3). Historically, the search for borrow areas containing compatible sand has been challenging because panhandle residents have demanded only bright, white sand be used to nourish their native beaches (c.f. Judnich, 2017). Permitted borrow areas have typically contained fine sand like the native beaches, but these deposits are often more poorly sorted and slightly darker (Figure 3).

The sedimentology of potential sand reserves is based primarily upon a limited number of reconnaissance-level grab samples, but the data suggest they do not contain sand compatible with the native beaches as it is generally coarser, more poorly sorted, and often darker (Figure 3). Should a subsequent and more detailed geotechnical survey of these areas reveal one, another, or all of the marine sand deposits are not compatible with native beaches, a discussion amongst stakeholders regarding the cost (i.e., loss of aesthetic and ecologic function) and benefits (i.e., protection of capital investment) of beach nourishment will surely follow. Compromises will likely be made to the scale of panhandle nourishment required to mitigate climate change.

\section{Construction costs}


The cost to nourish beaches along the Florida panhandle has steadily risen from about $\$ 5 \mathrm{~m}^{-3}$ during the late twentieth century to more than $\$ 10 \mathrm{~m}^{-3}$ over the past decade (Figure 4, Supplemental Table 4). Construction bids now often exceed a project's budget. For example, bids to nourish Gulf County's St. Joseph Peninsula were 150\% to 300\% higher than expected (c.f. Croft, 2017). Prices ranged from $\$ 15 \mathrm{~m}^{-3}$ to $\$ 26 \mathrm{~m}^{-3}$.

The projected annual cost to sustain an 84-year beach nourishment program along the Florida panhandle is shown in Table 1. Costs range between \$47.1 and \$72.6 million per year, depending upon the sea level rise scenario that ultimately materializes. For perspective, the average annual Federal expenditure on all shore protection projects constructed in the United States by the Army Corps of Engineers between 1950 and 1993 was only \$17 million (National Research Council, 1995). Our estimates assume the cost per cubic yard of emplaced sand stays constant at $\$ 30 \mathrm{~m}^{-3}$ until the end of this century. They are therefore conservative given historical construction costs, as measured per cubic meter of emplaced sand, have been rising about $\$ 5$ every 15 years (Figure 4). At the current rate of rise, the cost of nourishment will exceed $\$ 30 \mathrm{~m}^{-3}$ by mid-century.

Between 2013 and 2017, the Florida legislature appropriated an average of \$3.8 million in support of the State's comprehensive long-term beach management plan for the panhandle (Supplemental Table 1). Local cost sharing was generally between $100 \%$ and $200 \%$ of the State appropriation. Even if it is assumed panhandle counties will continue to receive about $20 \%$ of the State's annual appropriations and the local match could be sustained at $200 \%$ throughout this century, the sum is not enough to pay for the annual nourishment of the panhandle shoreline under even the lowest (RCP2.6) sea level rise scenario as proposed by Houston (2017).

To complicate matters, construction costs will surely rise as the search and recovery of sand moves further offshore (Figure 2 ) and the requisite volume increases in response to a nonlinear acceleration in the rate of sea level rise (Sweet et al., 2017) and increasing storminess (USGCRP, 2017), neither of which Houston (2017) factored into his analysis. It is thus highly probable annual construction costs to nourish panhandle beaches will quickly overwhelm existing local and state program budgets.

\section{Coastal geomorphology}

Coastal geomorphology (i.e., landform, topography) dictates the magnitude and extent of erosion and flooding caused by sea level rise and storms. As a case in point, the coastal geomorphology of the Florida panhandle was evaluated using photogrammetry and digital elevation models to identify areas at risk to erosion and flooding (see Supplemental Text DEM Methodology). In all seven counties, vulnerability was not limited to the oceanic shoreline (Figure 5, Supplemental Table 5) and therefore their nourishment alone will not mitigate the effects of climate change. The protect and defend strategy of beach nourishment would have 
to be expanded to include all vulnerable shorelines (i.e., back barrier, mainland, embayment, riverine, tidal, lacustrine). The expansion of depression ponds on the barrier island would also have to be addressed, as would vulnerable low-lying infrastructure (i.e., roads, gravity driven sewer and storm water systems).

A more realistic assessment must address the risks associated with all vulnerable geomorphic elements of the landscape, which will undoubtedly require even more resources to design and construct.

\section{Environmental impacts}

Historically, the ecological and associated economic value of beaches have generally been undervalued (c.f. Bush et al., 2004; Schlacher et al., 2007). And even though beach nourishment is considered the most environmentally-friendly option for shore protection, myriad impacts at all spatial and temporal scales have been well documented in the scientific literature (c.f. Greene, 2002; Viola et al., 2014). Despite decades of expensive, agency-mandated monitoring, the cumulative effects of marine dredge and fill projects are still poorly constrained (Defeo et al., 2009; Peterson and Bishop, 2005; Wooldridge et al., 2016). Speybroeck et al. (2006) list several ecologically sound practices that could minimize the cumulative environmental impacts of beach nourishment including (1) the use of compatible fill and (2) construction of a number of small projects rather than a single large one. Given what is currently known about the compatibility of Florida panhandle's marine sand reserves and the scale of nourishment required to mitigate climate change, it would appear neither of these strategies could be implemented. Furthermore, the scale of dredging required to generate the necessary sand volume is an order of magnitude larger than all projects constructed or permitted to date (Figure 2). How will this be viewed by local stakeholders or State and Federal agencies charged with environmental and species protection?

\section{Global implications}

The literature is replete with discussions of the effects of climate change on the worlds' coastlines and the potential use of beach nourishment as an effective mitigation strategy. However, there appear to be only a limited number of published studies (Table 2) designed to consider the full range of ecologic, economic, technical details required to determine whether such a strategy is actually viable. All of these studies should be considered an important first step, but there exist several significant limitations to the scope of each that constrain their utility. For example, while the volume of sand required to mitigate erosion was always considered, in less than half of the cases were potential sand sources identified and in no case was the quality or quantity of sand evaluated at the appropriate level of detail. In only one study was the compatibility of fill considered relative to the native beach(es). While project cost estimates were included in three of the seven investigations, these relied upon current market conditions that cannot be used to develop an accurate projection of construction costs through the end of this century. In all cases, the investigators focused only on the oceanic 
shoreline; one of many potentially vulnerable geomorphic elements of the coastal landscape. And finally, the environmental impacts of beach nourishment were either omitted or discussed at the conceptual level of detail. Clearly, a more robust analysis of beach nourishment as a potentially viable strategy to mitigate climate change must be conducted before any adaptive management decisions are made at any level of governance.

\section{Concluding remarks}

Nourishment of oceanic beaches along the Florida panhandle to mitigate climate change at the scale proposed by Houston (2017) is simply not sustainable given available information about marine sand reserve compatibility, construction costs, risks posed to geomorphic features other than the oceanic coast, and living marine resources subject to repetitive construction events. A review of similar analyses conducted at global to regional scales indicates these limitations are not uncommon. It follows their conclusions regarding the viability of beach nourishment as a cost-effective, long-term management strategy to mitigate climate change are subject to question.

The nourishment of oceanic beaches as historically constructed will surely continue over the next several decades. But this must be considered a near-term strategy to address existing vulnerabilities associated with coastal erosion and inundation. In the long-term, the risks posed to most developed coastlines by climate change will ultimately have to be addressed by a robust, adaptive management strategy that incorporates managed withdrawal from the shoreline.

\section{Acknowledgements}

We gratefully acknowledge Florida Department of Environmental Protection, Division of Water Restoration Assistance Beach Funding and the Beaches, Inlets and Ports Program for providing assistance during the data mining phase of this analysis. Andy Coburn, Associate Director of the Program for the Study of Developed Shorelines, provided historical beach nourishment construction cost data for the Florida panhandle. This is Publication Number $\mathrm{X}$ of the Sea Level Solutions Center, Florida International University.

\section{References}

Bird, E.C.F., 1985. Coastline changes. A global review. John Wiley and Sons, Chichester. Bush, D.M., Neal, W.J., Longo, N.J., Lindeman, K.C., Pilkey, D.F., Esteves, L.S., Congleton, J.D., Pilkey, O.H., 2004. Living with Florida's Atlantic Beaches: Coastal Hazards from Amelia Island to Key West, Living with the Shore. Duke Universiity Press, Durham, N.C.

Church, J.A., Clark, P.U., Cazenave, A., Gregory, J.M., Jevrejeva, S., Levermann, A., Merrifield, M.A., Milne, G.A., Nerem, R.S., Nunn, P.D., Payne, A.J., Pfeffer, W.T., Stammer, D., Unnikrishnan, A.S., 2013. Sea Level Change, in: Stocker, T.F., Qin, D., Plattner, G.-K., Tignor, M., Allen, S.K., Boschung, J., Nauels, A., Xia, Y., Midgley, P.M. (Eds.), Climate Change 2013: The Physical Science Basis, Contribution of Working Group I to the Fifth 
Assessment Report of the Intergovernmental Panel on Climate Change. Cambridge University Press, Cambridge, United Kingdom and New York, N.Y., USA, pp. 1137-1216.

Church, J.A., White, N.J., 2011. Sea-Level Rise from the Late 19th to the Early 21st Century. Surv Geophys 32, 585-602.

Cooke, B.C., Jones, A.R., Goodwin, I.D., Bishop, M.J., 2012. Nourishment practices on Australian sandy beaches: A review. Journal of Environmental Management 113, 319-327.

Croft, T., 2017. Beach Restoration Bids Far Exceed Budget [WWW Document]. The Star, Port St. Joe. URL http://www.starfl.com/news/20171026/beach-restoration-bids-far-exceedbudget (accessed 6.12.18).

Defeo, O., McLachlan, A., Schoeman, D.S., Schlacher, T.A., Dugan, J., Jones, A., Lastra, M., Scapini, F., 2009. Threats to sandy beach ecosystems: A review. Estuarine, Coastal and Shelf Science 81, 1-12.

Gornitz, V.M., Danielst, R.C., White, T.W., BirdwellII, K.R., 1994. The Development of a Coastal Risk Assessment Database: Vulnerability to Sea-Level Rise in the U.S. Southeast. Journal of Coastal Research, Coastal Hazards 327-338.

Greene, K., 2002. Beach Nourishment: A Review of the Biological and Physical Impacts (No. 7), Habitat Management Series. Atlantic States Marine Fisheries Commission, Washington, D.C.

Hamm, L., Capobianco, M., Dette, H.., Lechuga, A., Spanhoff, R., Stive, M.J.., 2002. A summary of European experience with shore nourishment. Coastal Engineering 47, 237-264.

Hinkel, J., Nicholls, R.J., Tol, R.S.J., Wang, Z.B., Hamilton, J.M., Boot, G., Vafeidis, A.T., McFadden, L., Ganopolski, A., Klein, R.J.T., 2013. A Global Analysis of Erosionof Sandy Beaches and Sea-Level Rise: An Application of DIVA. Global and Planetary Change 111, 150-158.

Hoffman, E., 2016. The Costs of Shoreline Stabilization [WWW Document]. URL http://southatlanticalliance.org/wp-content/uploads/2016/04/17-Hoffman-The-Costsof-Shoreline-Stabilization.pdf (accessed 6.12.18).

Houston, J.R., 2017. Shoreline Change in Response to Sea-Level Rise on Florida's West Coast. Journal of Coastal Research 336, 1243-1260.

Judnich, T., 2017. Okaloosa Aims to Keep Using White Beach Sand [WWW Document]. Northwest Florida Daily News. URL http://www.nwfdailynews.com/news/20170226/okaloosa-aims-to-keep-using-whitebeach-sand (accessed 6.12.18).

Langedijk, J.M.P.A., 2008. Beach nourishment to mitigate the impact of sea level rise in southeast Australia (Master of Science). Delft University of Technology, Delft.

Leatherman, S.P., 1996. Shoreline Stabilization Approaches in Response to Sea Level Rise: U.S. Experience and Implications for Pacific Island and Asian Nations, in: Erda, L., Bolhofer, W.C., Huq, S., Lenhart, S., Mukherjee, S.K., Smith, J.B., Wisniewski, J. (Eds.), Climate Change Vulnerability and Adaptation in Asia and the Pacific. Springer Netherlands, Dordrecht, pp. 149-157.

Leatherman, S.P., 1989. Sea Level Rise, in: Smith, J.B., Tirpak, D. (Eds.), National Assessment of Beach Nourishment Requirements Associated with Accelerated Sea Level Rise, The Potential Effects of Global Climate Change on the United States. Report to Congress, p. 30. 
National Research Council, 1995. Beach Nourishment and Protection. National Academy Press, Washington, D.C.

National Research Council, 1987. Responding to Changes in Sea Level: Engineering Implications. National Academies Press, Washington, D.C.

Nicholls, R.J., Cazenave, A., 2010. Sea-level rise and its impact on coastal zones. science 328, 1517-1520.

Nicholls, R.J., Wong, P.P., Burkett, V.R., Codignotto, J.O., Hay, J.E., McLean, R.F., Ragoonaden, S., Woodroffe, C.D., 2007. Coastal Systems and Low-Lying Areas, in: Climate Change 2007: Impacts, Adaptation and Vulnerability, Contribution of Working Group II to the Forth Assessment Report of the Intergovernmental Panel on Climate Change. Cambridge University Press, Cambridge, UK, pp. 315-356.

Peterson, C.H., Bishop, M.J., 2005. Assessing the Environmental Impacts of Beach Nourishment. BioScience 55, 887-896.

Peterson, C.H., Bishop, M.J., Johnson, G.A., D’Anna, L.M., Manning, L.M., 2006. Exploiting beach filling as an unaffordable experiment: Benthic intertidal impacts propagating upwards to shorebirds. Journal of Experimental Marine Biology and Ecology 338, 205-221.

Schlacher, T.A., Dugan, J., Schoeman, D.S., Lastra, M., Jones, A., Scapini, F., McLachlan, A., Defeo, O., 2007. Sandy Beaches at the Brink: Sandy Beach Conservation Crisis. Diversity and Distributions 13, 556-560.

Speybroeck, J., Bonte, D., Courtens, W., Gheskiere, T., Grootaert, P., Maelfait, J.-P., Mathys, M., Provoost, S., Sabbe, K., Stienen, E.W.M., Lancker, V.V., Vincx, M., Degraer, S., 2006. Beach Nourishment: An Ecologically Sound Coastal Defence Alternative? A Review. Aquatic Conservation: Marine and Freshwater Ecosystems 16, 419-435.

Sweet, W., Kopp, R., Weaver, C., Obeysekera, J., Horton, R.M., Thieler, E.R., Zervas, C.E., 2017. Global and regional sea level rise scenarios for the United States (NOAA Technical Report No. NOS CO-OPS 083). Sivler Spring, Maryland.

Titus, J.G., Park, R.A., Leatherman, S.P., Weggel, J.R., Greene, M.S., Mausel, P.W., Brown, S., Gaunt, C., Trehan, M., Yohe, G., 1991. Greenhouse Effect and Sea Level Rise: The Cost of Holding Back the Sea. Coastal Management 19, 171-204.

USGCRP, 2017. Climate Science Special Report: A Sustained Assessment Activity of the U.S. Global Change Research Program (Special). U.S. Global Change Research Program, Washington D.C.

Viola, S.M., Hubbard, D.M., Dugan, J.E., Schooler, N.K., 2014. Burrowing inhibition by fine textured beach fill: Implications for recovery of beach ecosystems. Estuarine, Coastal and Shelf Science 150, 142-148.

Wooldridge, T., Henter, H.J., Kohn, J.R., 2016. Effects of beach replenishment on intertidal invertebrates: A 15-month, eight beach study. Estuarine, Coastal and Shelf Science 175, 24-33.

Yoshida, J., Udo, K., Takeda, Y., Mano, A., 2014. Framework for Proper Beach Nourishment as An Adaptation to Beach Erosion Due to Sea Level Rise. Journal of Coastal Research 70, 467-472. 


\section{FIGURE CAPTIONS}

Figure 1. Location of seven coastal counties of the Florida panhandle. Also shown are locations of six LIDAR-based topographic surveys shown in Figure 5.

Figure 2. Balloon scatter plot of permitted borrow area and potential sand reserve centroid distance to shoreline and relative sand volume (balloon diameter). Data from Supplemental Table 2.

Figure 3. Scatter plot of panhandle native beach, permitted borrow area, and potential sand reserve granularmetrics. Permitted borrow areas are more poorly sorted than native beaches. Potential sand reserves differ from native beaches in mean grain size and sorting. Series shading proportional to color of sand. Data from Supplemental Table 3.

Figure 4. The cost of historical beach nourishment as a function of construction year and project type. Linear fit trend lines for emergency (solid) and planned (dashed) projects indicate costs, as measured per cubic meter of emplaced sand, are rising about $\$ 5$ every 15 years. Data from Supplemental Table 4.

Figure 5. Six randomly selected LIDAR-based topographic profiles (meters) constructed shorenormal to range monuments $(\mathrm{R})$ installed and maintained by FDEP. Horizontal lines represent minimum $(0.38 \mathrm{~m})$ and maximum $(0.68 \mathrm{~m}$ ) range of sea level rise used by Houston (2017). In addition to the oceanic $(\mathrm{O})$ shoreline, flooding and/or erosion will occur along the shoreline of swales (S), the backbarrier (B), lakes (L), tidal creeks (T), and estuaries/bays (E). See Figure 1 for monument locations. Walton and Bay County scale $(V E=90)$ different from others (VE $=65)$. 


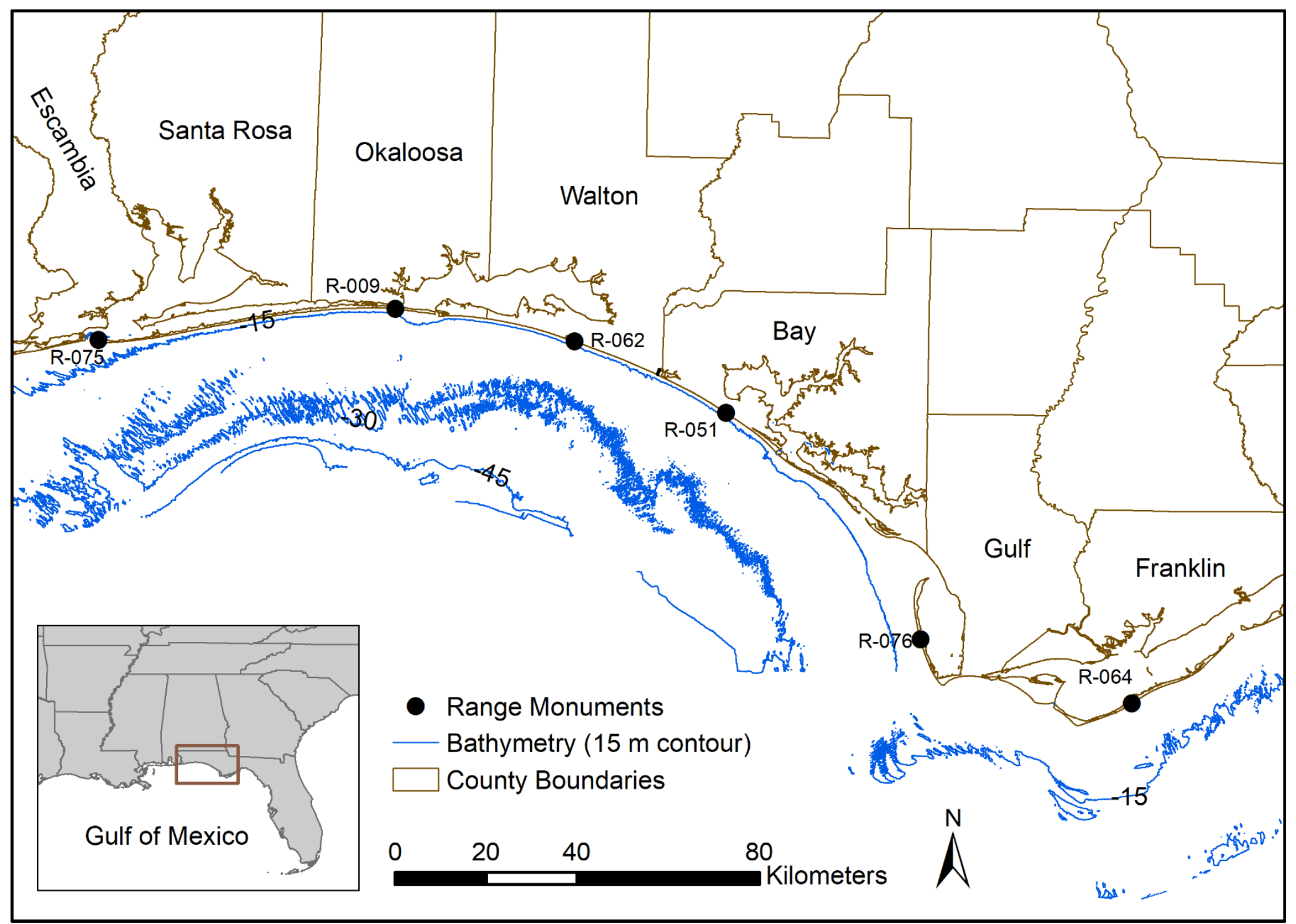

Figure 1 


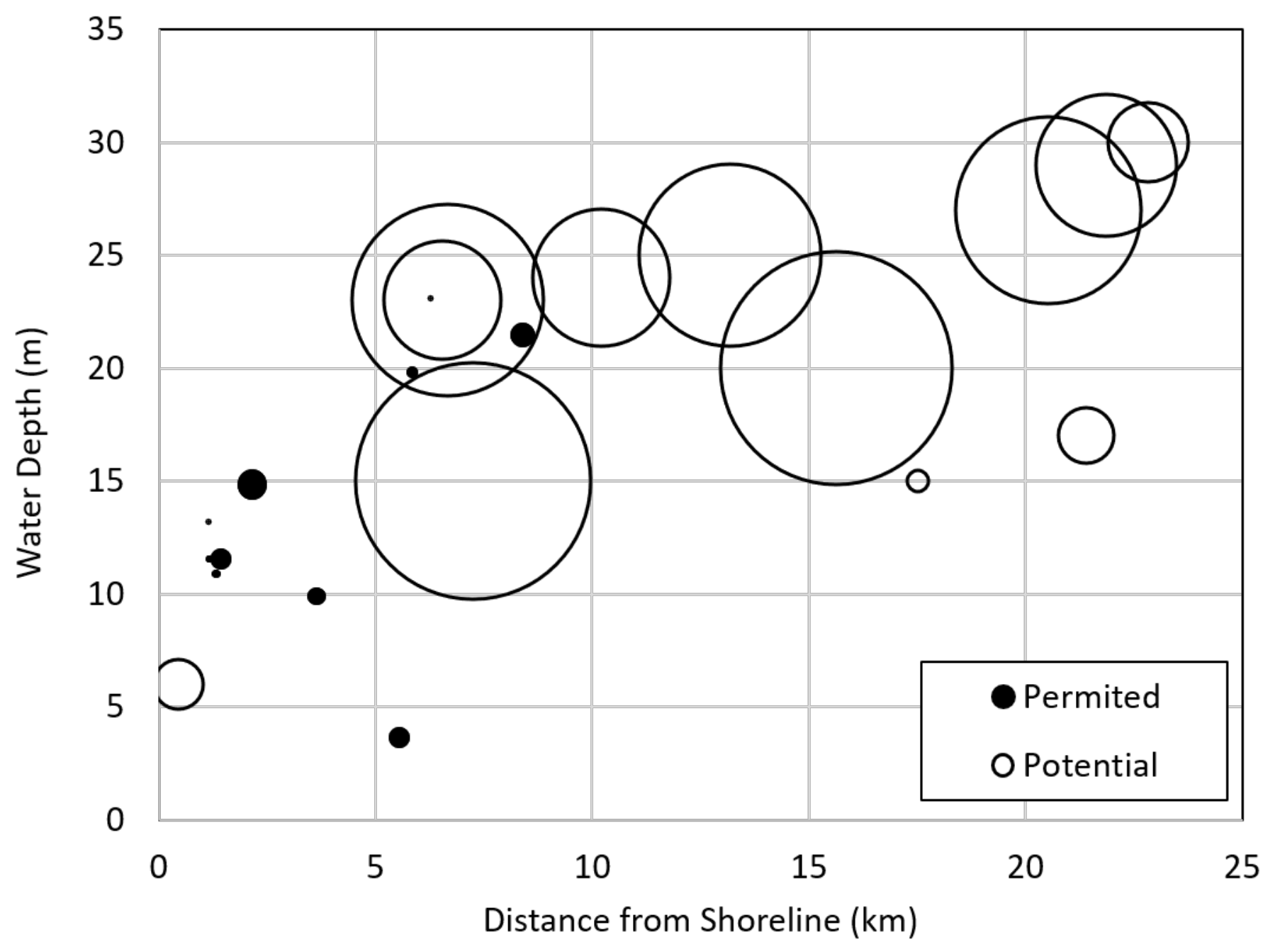

Figure 2 


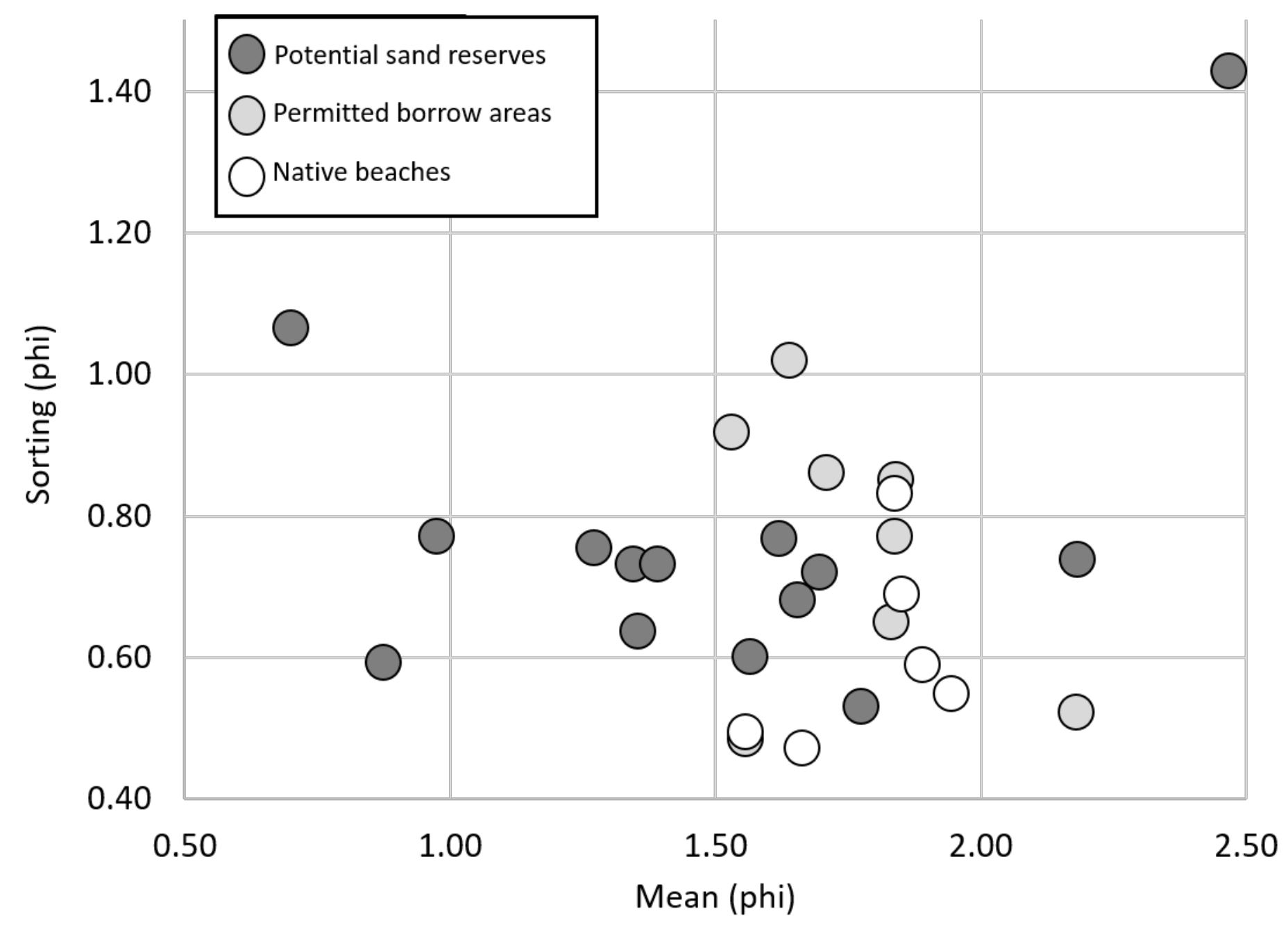

Figure 3 

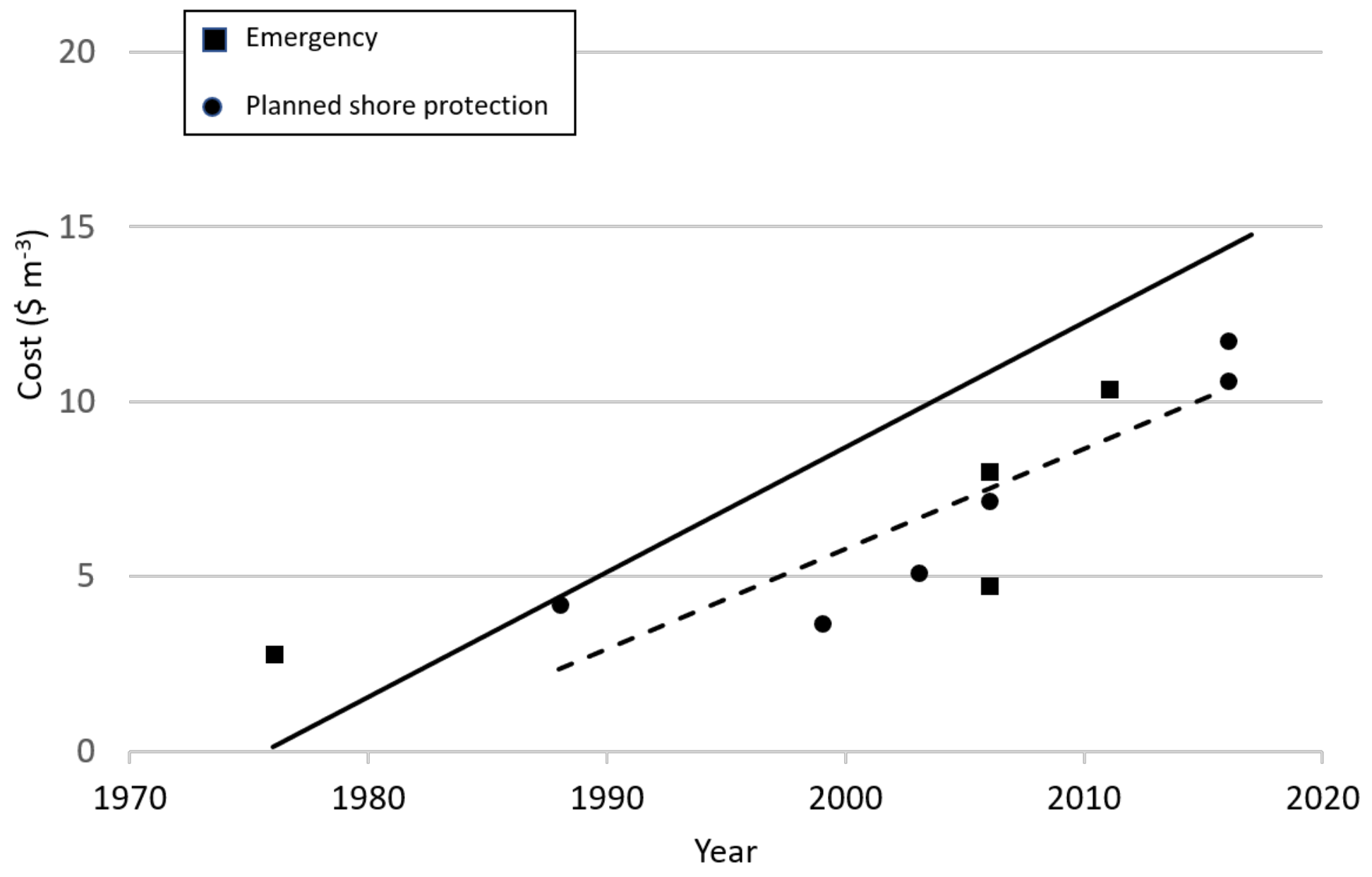

Figure 4 


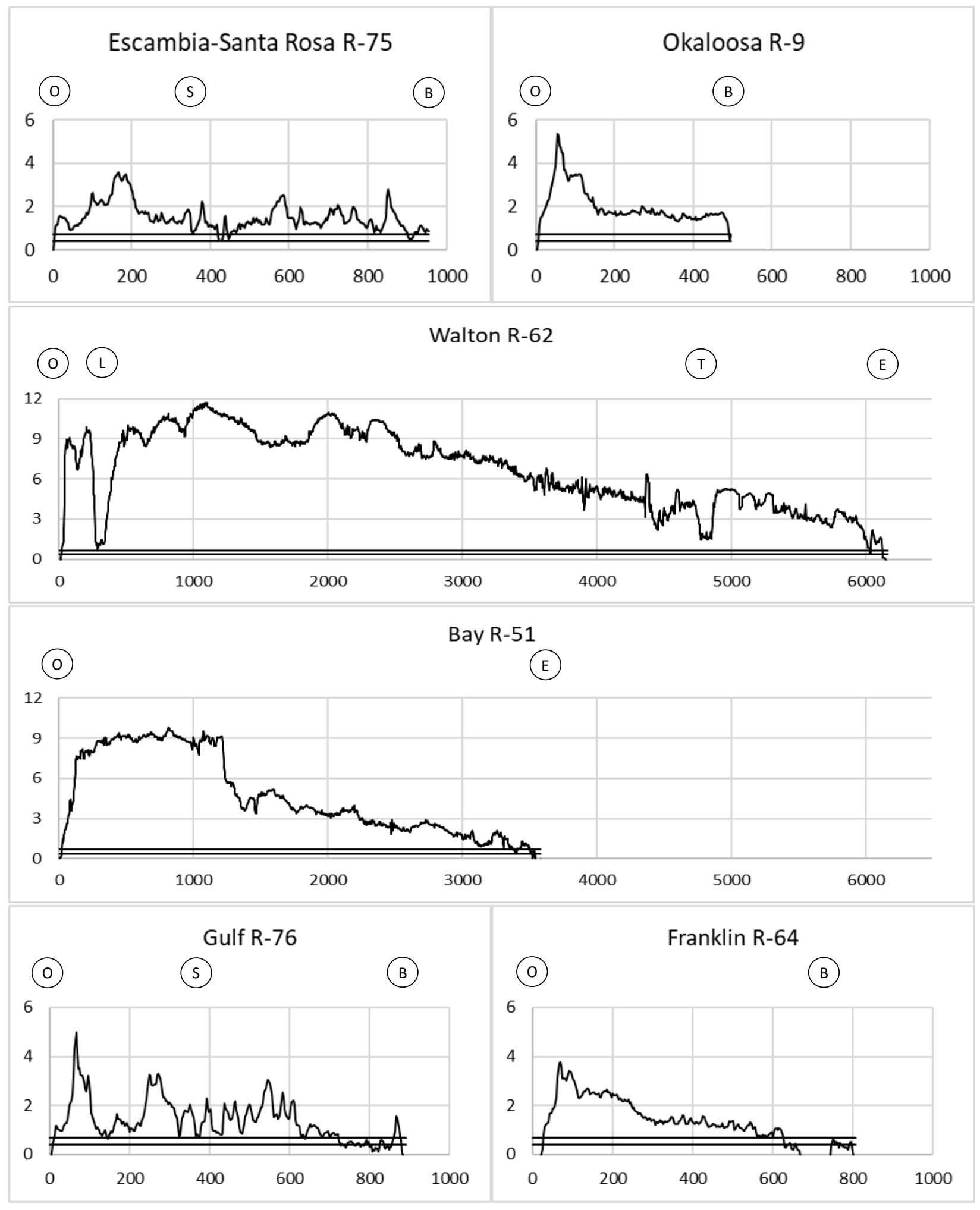

Figure 5 
Table 1. Annual beach nourishment sand requirements proposed by Houston (2017) to maintain the Florida panhandle's 2016 shoreline position under four IPCC ( Church et al., 2013) sea level rise scenarios until the end of this century. Also shown are estimated annual construction costs, held constant at $\$ 30 \mathrm{~m}^{-3}$ and average annual State cost sharing to design and construct non-Federal planned beach nourishment projects. Appropriation data from Supplemental Table 1.

\begin{tabular}{|c|c|c|c|c|c|c|c|c|c|c|}
\hline \multirow[b]{2}{*}{ County } & \multicolumn{4}{|c|}{$\begin{array}{l}\text { Average annual sand volume } \\
\text { requirements }\left(\mathrm{m}^{3} \times 10^{6}\right)\end{array}$} & \multicolumn{4}{|c|}{ Average annual cost $\left(\$ \times 10^{6}\right)$} & \multicolumn{2}{|c|}{$\begin{array}{l}\text { Average annual State appropriation } \\
\qquad \text { FY } 2013-2017\left(\$ \times 10^{6}\right)\end{array}$} \\
\hline & $\mathrm{RCP} 2.6$ & RCP4.5 & RPC6.0 & RCP8.5 & RCP2.6 & RCP4.5 & RPC6.0 & RCP8.5 & Requested & Received \\
\hline $\begin{array}{l}\text { Escambia } \\
\text { Santa Rosa }\end{array}$ & 0.21 & 0.26 & 0.27 & 0.37 & 6.3 & 7.8 & 8.1 & 11.1 & 6.5 & 1.8 \\
\hline Okaloosa & 0.08 & 0.10 & 0.10 & 0.14 & 2.4 & 3.0 & 3.0 & 4.2 & 0.0 & 0.0 \\
\hline Gulf & 0.25 & 0.27 & 0.28 & 0.33 & 7.5 & 8.1 & 8.4 & 9.9 & 2.3 & 1.0 \\
\hline Franklin & 0.10 & 0.13 & 0.13 & 0.19 & 3.0 & 3.9 & 3.9 & 5.7 & 0.0 & 0.0 \\
\hline Total & 1.57 & 1.81 & 1.84 & 2.42 & 47.1 & 54.3 & 55.2 & 72.6 & 9.7 & 3.8 \\
\hline
\end{tabular}


Table 2. Components of published studies designed to evaluate the utility of beach nousinment as a viable strategy to mitigate climate change.

\begin{tabular}{|c|c|c|c|c|c|c|}
\hline Location & Potential borrow areas & $\begin{array}{l}\text { Native beach } \\
\text { compatibility }\end{array}$ & Cost estimate & $\begin{array}{c}\text { Geomorphic } \\
\text { feature(s) }\end{array}$ & $\begin{array}{l}\text { Environmental } \\
\text { impacts }\end{array}$ & Source \\
\hline Global & No & No & Yes (method could not be determined) & Oceanic shoreline & No & Hinkel et al. 2013 \\
\hline Austrailia & Yes (reconnaissance-level) & No & Yes (current market conditions) & Oceanic shoreline & Yes (conceptual) & Langedijk 2008 \\
\hline Europe & No & No & No & Oceanic shoreline & No & Hamm et al. 2002 \\
\hline Japan & No & No & No & Oceanic shoreline & No & Yoshida et al. 2014 \\
\hline USA & Yes (reconnaissance-level) & No & Yes (current market conditions) & Oceanic shoreline & No & Leatherman 1989 \\
\hline USA & Yes (conceptual) & Yes (conceptual) & No & Oceanic shoreline & Yes (conceptual) & NRC 1987 \\
\hline Florida panhandle, USA & No & No & No & Oceanic shoreline & No & Houston 2017 \\
\hline
\end{tabular}




\section{Supplemental Text: DEM Methodology}

Six shore normal topographic profiles were generated from digital elevation models (DEMs) with 1.5 m horizontal resolution using LiDAR data collected from 2007 to 2009 . Profile locations were randomly selected using FDEP survey monuments in each of the county. Escambia and Santa Rosa Counties were combined as in Houston (2017). Each profile extended from the oceanic coastline to an interior waterbody or $3 \mathrm{~km}$. Survey monuments were selected using the Python function SelectRandomByCount. Elevation was extracted along each profile at $3 \mathrm{~m}$ intervals. Elevation is reported in reference to the NAVD88 vertical datum in meters. Sample locations falling within NOAA's Vdatum v.3.7 transformation grid were converted to LMSL (m) to determine the magnitude of difference between vertical datums. The average difference was $6 \mathrm{~cm}$ and was as high as $22 \mathrm{~cm}$. For our purposes, NAVD88 is sufficiently coincident with LMSL in the panhandle of Florida.

DEMs were obtained from the Florida Division of Emergency Management Coastal LIDAR Mapping Project (http://fldem.ihrc.fiu.edu/fldemlidar20120119/Default.aspx). Monument locations were obtained from the FDEP Regional Offshore Sand Source Inventory (http://rossi.urs-tally.com/Home/Downloads). All data were projected into the 1983 HARN Florida State Plane FIPS survey feet to correspond with the coordinate system of the DEMs. County boundaries were obtained from TIGER/Line 2010 Census data. The coastline was originally digitized in 1990 and updated in 2004 by the Florida Fish and Wildlife Research Institute (FWRI). 


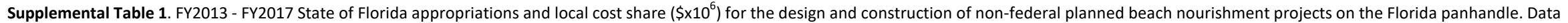
from FDEP (2017).

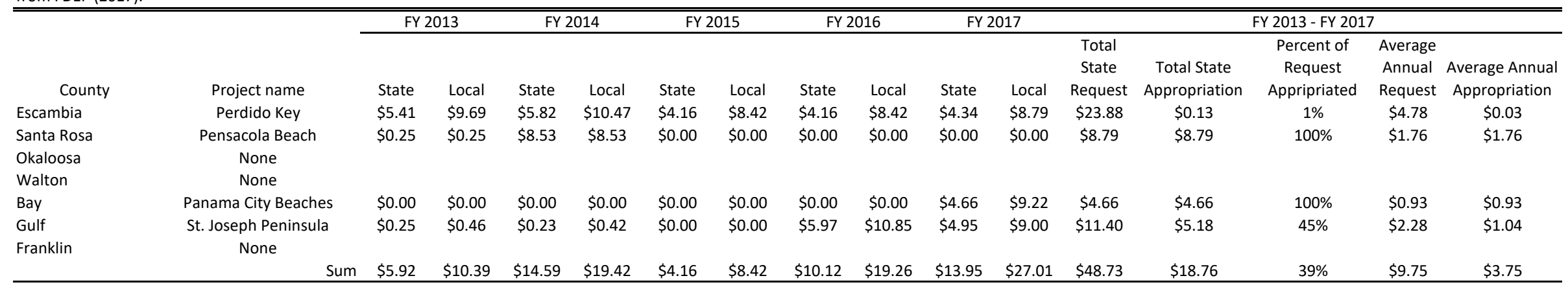


Supplemental Table 2. Summary of (a) permitted borrow area and (b) potential sand reserve field data, Florida panhandle.

Shoreline distance measured to centroid. $n d=$ no data. Sources include this study and FDEP (2017a and 2017b).

\begin{tabular}{|c|c|c|c|c|c|c|c|c|c|}
\hline & County & Name & $\begin{array}{l}\text { Distance } \\
\text { from } \\
\text { shoreline } \\
(\mathrm{km})\end{array}$ & $\begin{array}{l}\text { Water } \\
\text { Depth } \\
(\mathrm{m})\end{array}$ & $\begin{array}{l}\text { Area } \\
\left(\mathrm{km}^{2}\right)\end{array}$ & $\begin{array}{c}\text { Volume } \\
\left(\times 10^{6} \mathrm{~m}^{3}\right)^{a}\end{array}$ & $\begin{array}{c}\text { \# grab } \\
\text { samples }\end{array}$ & \# cores & $\begin{array}{c}\text { Seismic } \\
\text { lines } \\
(\mathrm{km})\end{array}$ \\
\hline \multirow{13}{*}{ a. } & Escambia & Offshore B Site & 8.4 & 21.5 & 1.4 & 4.0 & 0 & 23 & 6.4 \\
\hline & Santa Rosa & Offshore Borrow Area & 8.5 & 21.5 & 0.8 & 1.0 & 0 & 21 & 0.0 \\
\hline & Okaloosa & OKA & 2.1 & 14.9 & 3.1 & 5.8 & 0 & 46 & 460.0 \\
\hline & Walton & None & & & & & & & \\
\hline & Bay & S1-A & 1.4 & 11.6 & 0.9 & 2.9 & 0 & 21 & nd \\
\hline & & 02 & 6.3 & 23.1 & 0.6 & 0.1 & 0 & 10 & nd \\
\hline & & 03 & 5.9 & 19.8 & 0.6 & 0.9 & 0 & 8 & nd \\
\hline & & $5 C$ & 1.2 & 11.6 & 0.0 & 0.4 & 0 & 15 & nd \\
\hline & & 6 & 1.2 & 13.2 & 0.2 & 0.1 & 0 & 13 & nd \\
\hline & & 11 & 1.3 & 10.9 & 0.1 & 0.5 & 0 & 3 & nd \\
\hline & Gulf & $\mathrm{F}$ & 3.6 & 9.9 & 1.9 & 2.3 & 0 & 18 & 1.5 \\
\hline & Franklin & AP3 (offshore) & 5.5 & 3.6 & 2.0 & 3.0 & 0 & 13 & 3.4 \\
\hline & Average & & 4.1 & 14.7 & 1.0 & 1.9 & & & \\
\hline \multirow{19}{*}{ b. } & Escambia & $A-1$ & 7.3 & 15 & 121 & 375.1 & 23 & 0 & 78 \\
\hline & & W-1 & 21.9 & 29 & 32 & 137.6 & 6 & 0 & 24 \\
\hline & & $w-2$ & 15.6 & 20 & 102 & 362.1 & 16 & 0 & 58 \\
\hline & & $W-3$ & 20.5 & 27 & 72 & 234.0 & 2 & 0 & 17 \\
\hline & Santa Rosa & None & & & & & & & \\
\hline & Okaloosa & W-4 & 6.5 & 23 & 40 & 96.0 & 13 & 10 & 33 \\
\hline & & W-5 & 10.2 & 24 & 57 & 128.3 & 12 & 125 & 40 \\
\hline & Walton & W-6 & 22.8 & 30 & 23 & 44.9 & 3 & 0 & 12 \\
\hline & Bay & $w-7$ & 22.4 & 32 & 43 & nd & 3 & 0 & 18 \\
\hline & & $W-8$ & 6.7 & 23 & 52 & 247.0 & 29 & 77 & 92 \\
\hline & & W-9 & 13.2 & 25 & 40 & 224.0 & 8 & 0 & 25 \\
\hline & Gulf & $\mathrm{E}-1$ & 21.4 & 17 & 8 & 22.8 & 0 & 0 & 0 \\
\hline & & E-1 adj & 5.6 & 9 & 104 & nd & 47 & 20 & 36 \\
\hline & Franklin & East 1 & 3.9 & 6 & 13 & nd & 5 & 0 & 8 \\
\hline & & East 2 & 13.4 & 9 & 19 & nd & 5 & 0 & 7 \\
\hline & & East 3 & 2.8 & 9 & 8 & nd & 0 & 0 & 4 \\
\hline & & $E-2$ & 17.5 & 15 & 2 & 4.0 & 2 & 0 & 2 \\
\hline & & $E-3$ & 0.5 & 6 & 4 & 18.2 & 0 & 0 & 0 \\
\hline & Average & & 12.5 & 16.0 & 43.5 & 157.8 & & & \\
\hline
\end{tabular}

${ }^{\mathrm{a}} 50 \%$ volume reduction is factored into this estimate to account for dredge exclusion zones (i.e., basal buffer, non-compatible, archeological) and losses during delivery and construction (c.f. Taylor Engineering 2007). 
Supplemental Table 3. Summary of available sedimentological data associated with (a) native beaches, (b) permitted borrow areas, and (c) potential sand reserves, Florida panhandle. Description based upon Unified Soils Classification System. na = not applicable. nd = no data. Sources include this study, Niedoroda et al. (2004), Phelps et al. (2011), and FDEP (2017a and b).

\begin{tabular}{|c|c|c|c|c|c|}
\hline & County & Location & Description & Sorting & Munsell Color \\
\hline \multirow{7}{*}{ a. } & Escambia & na & fine sand & well & white \\
\hline & Santa Rosa & na & fine sand & well & white \\
\hline & Walton & na & fine sand & well & white \\
\hline & Okaloosa & na & fine sand & well & white \\
\hline & Bay & na & fine sand & moderately well & white \\
\hline & Gulf & na & fine sand & moderately well & white \\
\hline & Franklin & na & fine sand & moderately well & white \\
\hline \multirow{12}{*}{ b. } & Escambia & Offshore B Site & fine sand & moderately well & white \\
\hline & Santa Rosa & Offshore Borrow Area & nd & nd & nd \\
\hline & Okaloosa & OKA & fine sand & well & white \\
\hline & Walton & None & na & na & na \\
\hline & Bay & S1-A & fine sand & poorly & white \\
\hline & & 2 & fine sand & moderately & light grey \\
\hline & & 3 & fine sand & moderately & light grey \\
\hline & & $5 C$ & fine sand & moderately & white \\
\hline & & 6 & fine sand & moderately & white \\
\hline & & 11 & fine sand & moderately & white \\
\hline & Gulf & $\mathrm{F}$ & fine sand & moderately & white to light grey \\
\hline & Franklin & AP3 (offshore) & fine sand & moderately & light grey \\
\hline \multirow{18}{*}{ c. } & Escambia & A-1 & fine sand & moderately well & light grey to brown \\
\hline & & W-1 & fine sand & moderately & dark grey to brown \\
\hline & & $W-2$ & fine sand & moderately well & light grey to dark brown \\
\hline & & W-3 & medium sand & moderately well & nd \\
\hline & Santa Rosa & None & na & na & na \\
\hline & Okaloosa & $W-4$ & medium sand & moderately well & dark brown \\
\hline & & W-5 & fine sand & moderately & light brown to dark grey \\
\hline & Walton & W-6 & fine sand & moderately & dark grey to brown \\
\hline & Bay & W-7 & medium sand & moderately & dark grey to brown \\
\hline & & $W-8$ & fine sand & moderately & dark brown \\
\hline & & W-9 & fine sand & poorly & dark brown \\
\hline & Gulf & $\mathrm{E}-1$ & nd & nd & nd \\
\hline & & E-1 adj & fine sand & moderately & nd \\
\hline & Franklin & East 1 & fine sand & moderately & nd \\
\hline & & East 2 & fine sand & moderately & nd \\
\hline & & East 3 & nd & nd & nd \\
\hline & & $E-2$ & fine sand & moderately & nd \\
\hline & & $\mathrm{E}-3$ & nd & nd & nd \\
\hline
\end{tabular}


Supplemental Table 4. Historical beach nourishment construction costs, expressed per cubic meter of emplaced sand. Emergency projects, triggered by storm erosion, are generally more expensive as a consequence of a compressed construction timeline. Data provided by Andy Coburn, Program for the Study of Developed Shorelines.

\begin{tabular}{|c|c|c|c|c|c|c|}
\hline Location & $\begin{array}{c}\text { Year } \\
\text { Completed }\end{array}$ & $\begin{array}{l}\text { Primary } \\
\text { Funding } \\
\text { Source }\end{array}$ & Justification & $\begin{array}{l}\text { Volume } \\
\left(\times 10^{6} \mathrm{~m}^{-3}\right)\end{array}$ & $\begin{array}{c}\text { Nominal } \\
\text { Project Cost }\end{array}$ & Cost $\left(\mathrm{m}^{-3}\right)$ \\
\hline Bay County: Panama City Beach & 1976 & Unknown & Emergency & 0.2 & $\$ 598,206$ & $\$ 2.82$ \\
\hline Okaloosa County: Destin & 1988 & State & Shore Protection & 0.1 & $\$ 482,724$ & $\$ 4.22$ \\
\hline Bay County: Panama City Beach & 1999 & Federal & Shore Protection & 9.0 & $\$ 33,000,000$ & $\$ 3.68$ \\
\hline Escambia County: Pensacola Beach & 2003 & Federal & Shore Protection & 3.9 & $\$ 20,000,000$ & $\$ 5.15$ \\
\hline Escambia County: Pensacola Beach & 2006 & Federal & Emergency & 2.1 & $\$ 10,000,000$ & $\$ 4.75$ \\
\hline Bay County: Panama City Beach & 2011 & Federal & Emergency & 1.3 & $\$ 13,300,000$ & $\$ 10.39$ \\
\hline Escambia County: Pensacola Beach & 2016 & State & Shore Protection & 1.6 & $\$ 17,000,000$ & $\$ 10.62$ \\
\hline Santa Rosa County: Navarre Beach & 2016 & State & Shore Protection & 1.2 & $\$ 14,000,000$ & $\$ 11.78$ \\
\hline Bay County: Panama City Beach & 2017 & Local & Emergency & 0.8 & $\$ 17,800,000$ & $\$ 23.17$ \\
\hline
\end{tabular}


Supplemental Table 5. Coastal geomorphology and vulnerability associated with six randomly selected LIDAR-based topographic profiles (Figure 5) constructed shore-normal to range monuments (R) installed and maintained by FDEP. See Figure 1 for monument locations.

\begin{tabular}{|c|c|c|c|c|c|}
\hline County & Monument & Description & Landform & Topography & Vulnerable Areas \\
\hline $\begin{array}{l}\text { Escambia and } \\
\text { Santa Rosa }\end{array}$ & $\mathrm{R}-75$ & Gulf Island National Seashore & $\begin{array}{l}\text { Prograding Holocene barrier } \\
\text { island sand spit }\end{array}$ & Ridge and swale & $\begin{array}{l}\text { Oceanic shoreline } \\
\text { Swale depressions } \\
\text { Backbarrier shoreline }\end{array}$ \\
\hline Okaloosa & $\mathrm{R}-9$ & Ft. Walton Beach & Urban barrier island & Anthropogenic & $\begin{array}{l}\text { Oceanic shoreline } \\
\text { Backbarrier shoreline }\end{array}$ \\
\hline Walton & R-62 & Blue Mountain Beach & Pleistocene mainland & Antecedent highlands & $\begin{array}{l}\text { Oceanic shoreline } \\
\text { Lake shoreline } \\
\text { Tidal creek } \\
\text { Estuary/bay shoreline }\end{array}$ \\
\hline Bay & $\mathrm{R}-51$ & Panama City Beach & Pleistocene mainland & Antecedent highlands & $\begin{array}{l}\text { Oceanic shoreline } \\
\text { Estuary/bay shoreline }\end{array}$ \\
\hline Gulf & $\mathrm{R}-76$ & St. Joseph Peninsula & $\begin{array}{l}\text { Prograding Holocene barrier } \\
\text { island sand spit }\end{array}$ & Ridge and swale & $\begin{array}{l}\text { Oceanic shoreline } \\
\text { Swale depressions } \\
\text { Backbarrier shoreline }\end{array}$ \\
\hline Franklin & $R-64$ & St. George Island & $\begin{array}{l}\text { Overwashed Holocene barrier } \\
\text { island }\end{array}$ & Overwash & $\begin{array}{l}\text { Oceanic shoreline } \\
\text { Backbarrier shoreline }\end{array}$ \\
\hline
\end{tabular}




\section{Supplemental References}

Florida Department of Environmental Protection, 2017. Beaches Funding [WWW Document]. URL https://floridadep.gov/wra/beaches-funding (accessed 6.13.18).

Florida Department of Environmental Protection, 2017a. BIPP Permits (JCPs and ERPs) by County| [WWW Document]. URL https://floridadep.gov/water/beaches-inletsports/content/bipp-permits-jcps-and-erps-county (accessed 6.13.18).

Florida Department of Environmental Protection, 2017b. Regional Offshore Sand Source Inventory [WWW Document]. URL http://rossi.urs-tally.com/ (accessed 6.13.18).

Taylor Engineering, 2007. Attachment B - Coastal Engineering Narrative, Eglin AFB/Okaloosa Island Beach Restoration Project. Florida Department of Environmental Protection, Tallahassee, Florida. 